\title{
Preliminary Identification of Interfaces for Certification and Transfer of TRU Waste to WIPP
}

\author{
W. J. Whitty \\ C. A. Ostenak \\ K. K. S. Pillay
}


CONTENTS

ABSTRACT

I. INTRODUCTION 1

II. WASTE SHIPPING ORGANIZATIONS 2

III. WIPP ORGANIZATION FOR ACCEPTING WASTE 2

IV. WIPP REQUIREMENTS FOR ACCEPTING WASTE 3

A. Waste Certification 3

$\begin{array}{ll}\text { B. Nonconforming Waste Packages } & 3 \\ \text { C. Data Package Transmission } & 4\end{array}$

V. STRUCTURE OF WASTE-SITE OPERATIONS
A. INEL
B. RFP
C. ORNL
D. Mound Facility
E. ANL
F. RHO
G. Los Alamos
H. SRP
I. $\mathrm{BCL}$

VI. CONCLUSIONS AND RECOMMENDATIONS 12

$\begin{array}{ll}\text { A. Certification Authcrity } & 12 \\ \text { B. Waste Certification Training } & 12 \\ \text { C. Waste Packaging } & 13 \\ \text { D. Waste Documntation } & 13 \\ \text { E. Standard Jels } & 13 \\ \text { F. Data Pr ssing } & 13 \\ \text { G. Additi. Concerns } & 13\end{array}$

ACKNOWLEDGMENTS $\quad 14$

REFERENCES

APPENDIX A: A SUMMARY OF WIPP WASTE ACCEPTANCE CRITERIA 15

APPENDIX B: PERSONNEL AND ORGANI ZATIONS CONTACTED 18

FIGURES

1. Typical wIfP operating-contractor organization. 3

2. Waste management organizational structure at INEL.

3. Waste management and related organizational structures at RFP.

4. Waste management organizational strurture at ORNL. 6

5. Waste management and related organizational structure at the Mound Facility.

6. Waste management and related organizational structure at $A N L$.

7. Waste managenent and related organizational structure at RHO.

8. Waste management and related organizational structure at Los Alamos.

9. Waste managenent and related organizational structure at SRP. 
PRELIMINARY IDENTIFICATION OP INTERFACES POR CERTIFICATION AND TRANSFER OF TRU MATE TO WIPP

by

W. J. Whitty, C. A. Ostenak, and K. K. S. Pillay

ABSTRACT

This study complements the national program to certify that newly generated and stored, unclassified defense transuranic (TRU) wastes meet the Waste Isolation Pilot Plant (WIPP) Waste Acceptance Criteria. The objectives of this study were to identify (1) the existing organizational structure at each of the major waste-generating and shipping sites and (2) the necessary interfaces between the waste shippers and WIPP.

The interface investigations considered ex loting waste management organizations the shipping sites and the proposed WIPP organization. An effort was made to identify the potential waste-certifying authorities and the lines of communication within these organizations. The long-range goal of this effort is to develop practicable interfaces between waste shippers and WIPP to enable the continued generation, interim storage, and eventual shipment of certified TRU wastes to WIPP. Soms specific needs identif led in this study include:

- organizational responsibility for certification procedures and quality assurance (QA) prograns;

- simple QA procedures; and

- specification and standardization of reporting forms and procedures, waste containers, and container labeling, color coding, and code location.

I. INTRODUCTION

The Tranauranic (TRU) Waste Management Progran is developing plans for the certification and shipment of unclassified defense Tru wastes to the Wate Itolation Pilot Plant (WIPP). A general set of requirements for these wastes to be shipped to WIPP was defined in a May 1980 report ${ }^{1}$ by the Steering Comittee on TRU waste Acceptance Criteria for WIPP. This report, sometiwes referied to as the WIPP-Mac, detail. WIPP waste Acceptance Criteria and discusese their technical bases. Minor changes to this document were proposed, ${ }^{2}$ and these are included in formal revilaion ${ }^{3}$ to the WIPP Waste acceptance Criteria.

The WIPP Waste Acceptance Criteris issued in

May 1980 emphasized criteria for the waste fores and the shipping containers for both contacthandled and remote-handled, unclassified defense TRU wastes. However, these TRU wastes are generated and stored in a variety of forms and storage modes at several sites in the US. Therefore, it is necesenty to develop a general plan for the certification of these wastes that can be made site-specific in its implementation. The Los A lamon National Laboratory Safeguards Systens Group was requested by the Transuranic waste systens office (TWSO), as part of the overall certification effort, to identify (1) the existing organizational structure at each of the waste-generating and ahipping sites, and (2) the necessary interfaces betwen the waste shippers and WIPP.

Members of the Los Alamos Safeguards systems

Group wet with the wajor TRU-waste generators and 
shippers and reviewed all relevant documentation. The renaining minor producers of TRU waste will be contacted during the continuation of this inveatigation in FY 1982. The investigation of the interfaces between TRU-waste generators and WIPP considered existing waste management organizational structures at shipping sites and the proposed organization for WIPP, including their potential waste-certifying atthorlties and their lines of communication. The long-range goal of this effort is to develop practicable interfaces between waste shippers and WIPP to enable the continued generation, interim storage, and eventual ahipment of certified TRU wastes to WIPP when it becomes operational. It is important to note that the organizational descriptions and the conclusions and recommendations in this report were written in August and September of 1981; hence, they reflect the status of the TRU-waste certification program up to that time.

II. WASTE SHIPPING ORGANIZATIONS

Collectively, several organizations participating in the US defense program have generated large quantities of contact-handled and lesser amounts of reme-handled TRu waste. The major producers of defense TRU waste are the Rocky Flats Plant (APP), ile contractors on the Hanford Reservation, the Savannah River Plant (SRP), the Mound Facility, and the Los Alamos Natlonal Laboratory. Smaller producers include the Argonne National Laboratory (ANL), the Oak Ridge National Laboratory (ORNL), the Lawence Livermore National Laboracory, Battelle Columbus Laboratories (BCL), the Bettid Atomic Power Laboratory, and the Idaho Nationel Engineering Laboratory (INEL). Moat of the readily recoverable TRU waste is in storage at INEL and at Hanford, and wost of the inventory at IKEL, ia from RPP.

When MIPP becomes operational (echeduled for 1949), all TRU-waste generators are expected to ship their certified contact-handled TRU waste directly to UIPP. Rewote-handled TRU wate also will be accepted at WIPP after they are certified.
All shipnente of TRU wate to WIPP nust comply with the regulations of the US Department of Transportation (DOT), the US Nuclear Regulatory Commission (NRC), and the individual states." The specific regulation are intended to ensure safety through standards established for packaging, handling, and ahipping radioactive materials. In addition to DOT, NRC, and any state regulations, all TRU waste shipped to WIPP nust first be certifled that it meets the WIPP Waste Acceptance Criteria.

II1. WIPP ORGANIZATION FOR ACCEPTING WASTE

The US Department of Energy (DOE) is the owner/applicant of WIPP, and Westinghouse is the potential contractor responsible to DOE for its operation. The proposed WIPP operating-contractor organization 1s shown in Pig. 1 . It includes a general manager who will have overall responsibilIty for the operation, maintenance, and modification of WIPP, and several subordinate managers. The waste management manager will be responsible for planning, scheduling, ano conducting wastehanding operations in an efficlent and economical manner that ensures safe plant operation. He will also be responsible for selecting the wasie-handling processes, which include waste receipt, inrpection, repackaging when required, and underground emplacement. Additionally, his responsibilitiea will include integrating the overall plant operation process flow according to established criteris and in compliance with all applicable health and afety regulations. 5

waste acceptance is scheduled to take place in the recelving and inspection area of the wistehandling building, where the packages will be surveyed and inapected for contanination or damage. The onipping papers will be chacked first to verify that the train or truck was scheduled for WIPP. The data packages and other certification documentation will be examined before adniseiton to the waste-handifing bullding. Waste shipments that eet certification requirements when dispatched, but are found in noncompliance at receipt, will be 


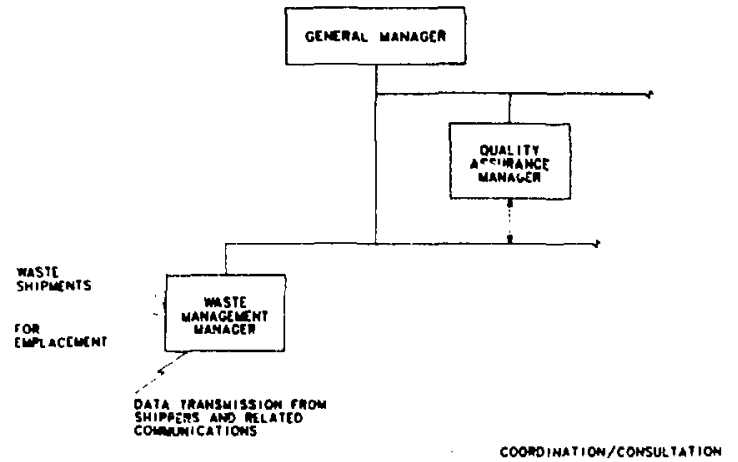

Fig. 1. Typical wIPP operating-contractor organlzation. (Adapted from Ref. 5.)

segregated until the appropriate action can be determined. Scheduling waste receipt is not anticipated to be a problem because adequate buffer storage capacity is planned for WIPP. Any scheduling problems probably will be related to the transportation link between the shipper and WIPP.

IV. WIPP REQUIREMENTS FOR ACCEPTING WASTE

The WIPP Waste Acceptance Criteria for unclassified TRU wastes resulting from national defense activities were developed to ensure that all waste transportation and wIPP operations take place safely. ${ }^{1,3}$ These criteria are not specifications but limits within which waste generators and shippers may develop their own procedures for the preparation of waste for shipment to wIPP. The WIPP waste Acceptance Criteria were updated by WIPP personnel to include pertinent comments suggested by the State of New Mexico Environmental Evaluation Group, the DOE Albuquerque Operations office, and the Certificacion Requirements Working Group. These criteria are sumarized in Appendix $A$.

TwSo prepared preliminary interpretations ${ }^{6}$ of the criteria in march 1981 for review by generators and shippers. As a follow up to the coments received, Twso prepared another document ${ }^{2}$ in July 1981 outlining compliance requizements necessary for certification of newly generated, contacthandled TRU waste, which was revised by the Cert1fication Requirement working Group. Further revisions of this document were iasued for review. The final version of the compliance requirements was issued as a WIPP-DOE series document. ${ }^{7}$ similar compliance requirements for stored, contact-handled TRU waste $w 111$ be developed in FY 1982.

The revilions to the WIPP waste Acceptance Criteria, as detailed in Ref5, 3 and 7 , make it possible for the waste generators and shippers to develop their own site-specific procedures for certifying that each of their waste packages meets the criteria. Therefore, no exceptions to the criteria will be made by the WIPP operator. However, the special needs of nonconforming and toxic waste packages will have to be addressed individually.

\section{A. Waste Certification}

Waste shipping organizations are required to provide the WIPP nperator with a data package that certifies that erich waste package in the shipment mets the WIPP vaste Acceptarce Criteria. Also, the waste shippers must maintain auditable waste documentation systems that include descriptions of the methods used for certification of their TRU waste, including the associated guality assurance (QA) programs. 1,3,7 The WIPP operator must be satisfled that the shipping-site certification procedures are valid. Therefore, a QA system auditable by DOE must be developed by each site to meet its specific needs. The audit authority within DOE has not been identified. Furthermore, the actual waste acceptance procedures and the QA program at WIPP must also be auditable. ${ }^{5}$ The DOE-WIPP Project Office is responslole for surveillance, monitoring, auditing, review, and approval of all QA functions performed by the major project participants during the site evaluation, design, and construction phases of WIPP. ${ }^{5,8}$ the responsibllity for $Q A$ at WIPP during the operational phase will rest with the WIPP operator.

\section{B. Nonconforming Waste Packages}

Waste packages that are certified when they are shipped, but are found to be in noncompliance upon receipt at WIPP, are considered nonconforming items. The receipt of nonconforming items should be infrequent, and they will be treated on site to make then safe for emplacement, or returned to the 
shipper under the approprlate DOT, NRC, and state regulations.

\section{Data Package Transindeion}

It has been proposed that all information regarding waste ahipments should be transmitted electronically to the MrPp central computer. This information, in addition to the required data packages, will include notification of the intent to ship and the mode of transportation. Any documentation or scheduling problems will be handled individually.

The VAx-type central computer will be part of the WIPP general computer system. It will have interactive and batch-processing capabilities and the ability to communicate off site with other computers. With properly designed hardware, software, peripheral equipment, and operating system, this computer should be able to handle easily the transmission of data packages. 9 Bechtel Incorporated, Nuclear Fuel Operations, the architectural-engineering firm for WIPP, is responsible for the design of the computer system. A systematic approach to establishing data transmission procedures should take into account the requirements of the shipper and WIPP.

\section{STRUCTURE OF WASTE-SITE OPERATIONS}

The FY 1981 task of the Los Alamos Safeguards Systems Group included initial contaces and discussions with the waste generating sites, storage sites, and westinghouse-wIPP. This effort started in April 1981 when we met with personnel from Twso, $B C L$, Pacific Northwest Laboratorles, and the Nuclear Quality Assurance Program office (KQAPO). NQAPO provided guldance on $Q A$ aspects of the certification effort. This guidance was further discussed between Los alamos Safeguards systems and Los Alamos Quality Assurance personnel. These meetings provided the QA framework and background for the discussions with waste generating and storage site operators and Westinghouse-wIPP. The following narrative pertains to our discussions with the waste gunerators and shippers. The wIPp operator was discussed in Sec. III and IV.
Our initial visjts were to Westinghouse-WIPP, EGEG Idaho, Inc., and RFP. These contacts were followed by visits to ORNL, Mound Facility, ANL, Rockwell Hanford Operations (RHO), Los Alamos National Laboratory, and SRP. BCL and Bettis Atomic Power Laboratory were contacted by telephone. BCL's small volume of TRU waste is from decontamination and decommissioning operations and will be shipped to INEL. Bettis ships their small volume of TRU waste to INEL and will be contacted again in FY 1982.

For a complete list of the individuals contacted, see Appendix $B$. The following discussion of individual site operations is presented in the order that the sites were visited.

A. INEL

Flgure 2 shows the waste management organization of EGG Idaho, Inc. Waste operations is responsible for accepting TRU waste for storage and eventual shipment to WIPP. Waste Programs is responsible for the design and development of waste certification procedures and for technology development. The DOE Idaho Operations office has been directed to design a stored Waste Retrieval Facility (SWRF) and a SWRF integrated with a TRU-waste Treatment Facility (TWTF). The SWRF and the TWTF are in the conceptual design stages, and this effort will continue through FY 1982. Certification of TRU wastes destined for WIPP will take

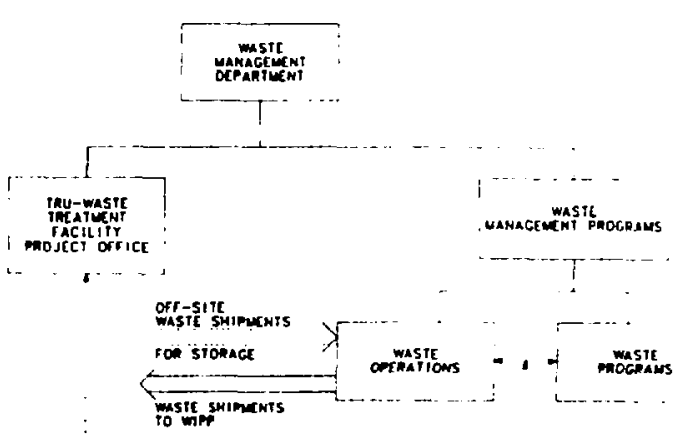

COONDINATION/CONSULTATION

Fig. 2. Waste management organizational structure at INEL. 
place in the SWRr. If waste needs to be proceseed to become certifiable, the plails are to use the TWTF.

Waste shipped to INEC for storage must meet acceptance criteria eatabliahed by EGsG Idaho, Inc. ${ }^{10}$ In some cases, these acceptance criteria are more atringent than those for WIPP. EGSG Idaho will start receiving certified waste from off site in FY 1982 for placement in certified storage. This certified wate will require further verifications before shipment to WIPP.

EGEG Idaho plans to start work in FY 1982 on stored waste certification procedures. Decisions by $D O E$ on the funding of processing facilities at INEL will have an impact on certification of stored wastes and possibly on certification of wastes shipped to INEL that cannot be certified by the shipper.

The certifying authority for stored wastes at INEL will be housed in the SWRF; however, this authority has not been identified because the organizational structure is just now being developed. Currently, the certification activities are managed by the waste Program Branch. EGs Idaho plans to meet with Westinghouse-WIPP personnel early in FY 1982 to discuss certification procedures.

EG ig Idaho, Inc. operates six waste information systems for DOE. Three of these Eystems are national in scope, and three are applicable to INEL only. The systems that are applicable to the national TRU program are the Solid Waste Information management system (SWIMS), 11 the Waste Management Information Syster (wiss), and the Transuranic Contaminated Waste Container Information syster (TCHCIS).

The SwIMS is a DOE-wide, central, automated information-management system that uses a master data base for describing the TRU and low-ievel wastes generated, disposed, or stored at DOE facilities to facilitate the management of solid-radioactive-waste management by DOE. All SWIMS data are separated into eight nuclide categories that include both contact-handled and remote-handled TRU wastes. The data are sumary in nature and include such paraneters as volume, weight, curies, nuclides, waste types, and waste treatment. This information is published annually and data are furnithed to the Integrated Data Base. (The Integrated Data Base is a DOE-supported system operated by ORNL and used for standardized radioactive-waste management and spent-fuel inventory data. 12,13,

The MMIS is an INEL data base that describes each shipment of solid waste for disposal or storage at the Radioactive Waste Management Complex (RHAC). The data include type, volume and number of containers, nuclide content, shipment weight, and storage/disposal location. This system provides information on inventory, generation data, etc.

The TCWCIS describes each container of TRU waste placed in RHMC storage since late 1971. Cunsequently, 278 s of the retrievable storage containers at INEL are descrited by this system. Specific data on each container include waste generator, container identification number, date packaged, waste combustibility and compactibility, content code, weight, dose rate, element weights, and shipment number.

B. RFP

The general structure of the RFP organizations related to waste management and certification is presented in Fig. 3. Rockwell International has set up a Waste Acceptance Criteria Development Team to investigate and solve problems that might prevent or delay certification of some TRU waste forms. The team comprises RFP personnel from

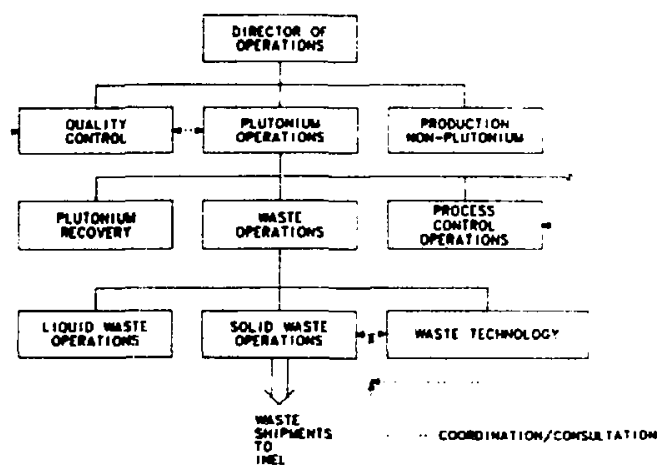

Fig. 3. Haste management and related organizational structure at RFP. 
on-1te laboratorles, RGD, TwSo, Quality Control, and waste Operations. The main problem requiring resolution at RFP concerns the imobilization of wastes that might produce respirable fines during handling. Waste Operation: wlll be responsible for developing RFP's certification procedures for certifying their TRU waste. The waste gemerators will be responsible for following their operating procedures. RFP has a good quality control (QC) program that interfaces with Plutonium Operations, waste Technology, and Solid waste Operations. Existing $Q C$ procedures are under review to determine the modifications necessary to make them applicable to certification.

Liquid waste streams will be handled, as much as possible, by process control. If the procese and inputs can be controlled, then the output can be certified without much difficulty. Visual inspection can play an important role in certifying steady-state processes. Line-generated wasten could present some problens, but coordination anong Quality Control, Plutonium Operations, and Waste Technology should lessen their impact on certif 1cation. The Quality Control office is instituting a staictical sampling program for line-generated and non-line-generated waste. A product audit will be conducted on $f$ inished waste ready for shipwent. A container QC program that has been in existence for 5 yrs will provide valuable knowledge for uning $Q C$ in the certification effort.

Several data processing ayutems aze in use at RFP. The waste Management Information system 14 (MMIS) " is a computerized data collection syaten used primarily to mointain data on wate containers shippeo to INEL and to provide sumenry reporting, including the quarterly swims report. Much of the data processed by the wirs is aleo required in the data packages necessary for certification. Modification of the wals output could provide certification data. In addition to the mis, an updated nuclear materials accountability systen is being set up to gather data on shipments. Billn of lading and other related materials are prepared for shipments. Monthly reports are prepered and

"Both RFP and INEL have systems that ues the ecronym wals; however, they are different oystems. -hipped to INEL through the Secure Automatic Com municatione Network (SACNET), a DOE sr jure system based in Germantown, Maryland, 15

It is felt that sone waste could be certified early in FY 1982 if decisions are made on container color coding, and if the requirements for data packages and ismobilization are specified. Other minor problems may also slow the certification of newly generated waste. When these decisions are made, certification of newly generated wastes should be possible at RFP. Existing procedures will help simplify certification so that some waste can be certified by the end of FY 1982 .

C. ORNL

Figure 4 shows the waste management structure at ORNL. ORNL waste management personnel have dicussed the need for certification in FY 1982 with the on-site waste generators, and plans for meeting the wrPp Waste Acceptance $C_{r}$ iteria will be developed in FY 1982. At present no internal waste certification is conducted, but the generators fill out forms that are checked periodically. A new Los Alamos assay system, soon to be delivered to ORNL, will provide an efficient monitoring sy ten for TRU-waste drums.

The waste management organization has a good QA progran that includes many of the items in the WIPP Waste Acceptance Criteria. However, TRU-waste druns are never opened, and the only documentation provided by generators is a statement about whether

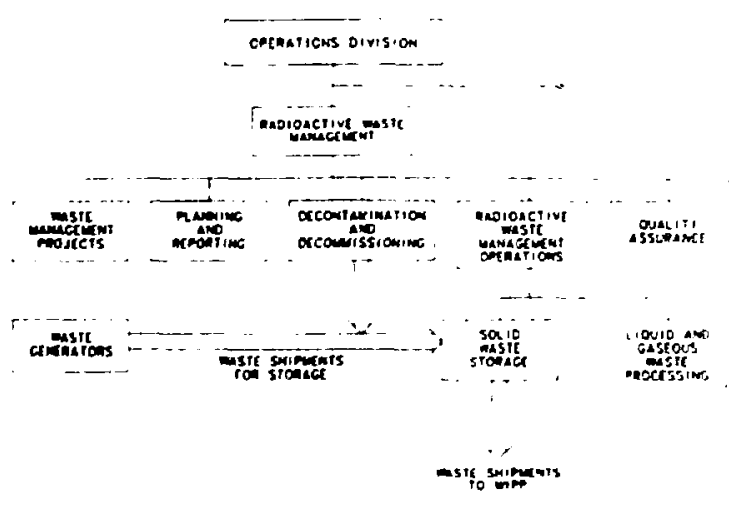

Fig. 4. Waste management organizational structure at ORNL. 
the drum TRU-waste concentration exceeds $10 \mathrm{mCl} / \mathrm{g}$. Thus, the generators are the certifying authorities now, but the shipper will have the ultimate responsibility when wate is shipped to WIPP. Ho internal certifying authority has been identified: however, data packages will be trananitted by the operations personnel.

ORNL has funded a FY 1982 study, similar to that at RFP, to investigate certification issues. They have made initial contacts with RFP personnel, and they anticipate that nearly all of FY 1982 will be required to develop plans and procedures. If will be difficult for ORNL to certify waste in FY 1982 except, perhaps, for a small quantity late in the year. ORNL personnel would prefer to let RFP personnel develop their certification procedures first.

\section{Mound Facility}

The Morssanto Research Corporation (Mound Facility) structure related to TRU-waste certification is shown in Fig. 5. Nearly all TRU waste produced at the Mound Facility is from decontanination and decomissioning operations. The bulk of this waste will be shipped to INEL before 1989 . Thereafter, a small amount of TRU waste will continue to be generated from normal operations. Mound's major problem is the need to use boxes larger than those approved for WIPP. After the decontamination and decommissionlng operations are terminated, container size will not be a problen.

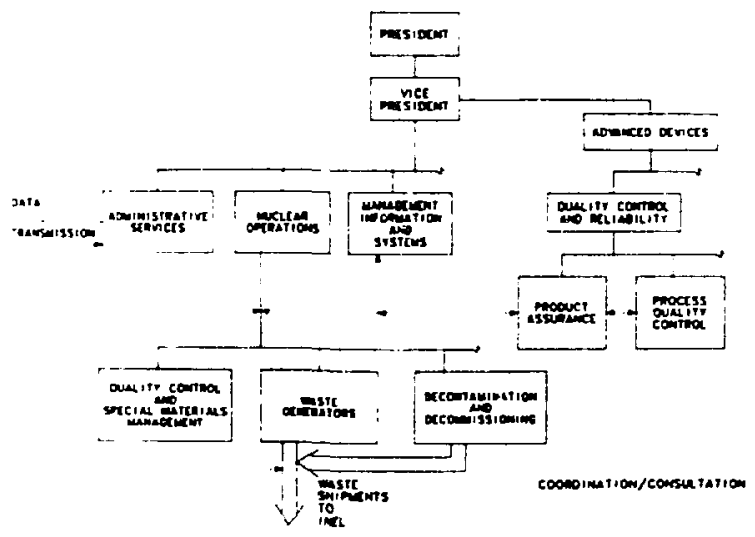

Fig. 5. Waste managewent and related organizational structure at the Mound Facility.
The problem of ovesaize boxes will require continued negotiation with FGG Idaho regarding acceptance and processing of this waste.

Mound exployees are developing plans for the certification of newly generated waste and for appropriate QA F-ocedures. A task force similar to that in existence at RFP bas been formed to develop plans for certifying waste and for identifying the funding necessary to implement these plans. Certification of some newly generated waste can occur late in FY 1982 if an external organization is available to approve their certification procedures and $Q A$ program. If a responsible organization is not available, Mound personnel are planning to request the Westinghouse-WIPP organization to review their procedures.

Three groups will be involved in certification at Mound: (1) the generating organization, (2) Quality Assurance, and (3) Administrative Services. The Quality Assurance office resides in the Quality Control and Reliability organization. The QA function has been mostly involved in container studies and in auditing TRU-waste-generating processes. The certification task force is investigating the compliance requirements and developing plans for a certification procedure that satisfies the requirements. Their concerns include immobilization, gas generation, and size reduction. Administrative Services is responsible for the packaging and subsequent transportation of waste to INEL. They will probably also be responsible for the transportation of waste to WIPP. If any newly generated waste is certified in FY 1982, it will probably consist of sludge that is cemented in 55-gal drums. No internal ceztifying authority has been identified for the shipment of newly generated waste.

The Mound Facility has three data systems that are integrated through the use of one of them, the waste Accountability, Shipping, and Packaging (mnsp) System. 16,17 All accountable nuclear aterial on site is managed by the Serial Number Recognition Accountability (SENRAC) system, ${ }^{17}$ which is a real-time accountability system. Shipments and receipts of nuclear aterial aze processed through a computerized tranefer system, the Automated-741 System, furniahed by the DOE Albuquerque Operation office. ${ }^{17,18}$ The wasp system 
stores packaging data and inapection results for each waste unit and prepares all necessary documents at the time of waste shipment to INEL. on1 ine interfaces enabl s rapld tranfer of information between the WaSP System and SENRAC, and the Automated-711 system. This is necessary because shipping documents produced by the Automated-741 System, in addition to the shipping reports generated by the WASP system, are required for each shipment of waste material. (A1) sites shipping waste must use DOE/NRC Form 741, Nuclear Material Transaction Report. 19,20 It is mentioned here beculse of its use with the wasp System.) The TwSo has provided Mound with FY 1982 funds to modify the waSP System to include all additional information that is necessary for certification but not already provided. Additional plans call for investigating the possible modification of the WASP system for other sites. Mound personnel plan to form a com mittee early in FY 1982, composed of different site representatives, to investigate different site needs and the feasibility of adapting the whSP system to these sites.

E. ANL

Figure 6 shows the structure related to waste management and certification at ANL. All TRU waste at ANL is produced in laboratories or as a refult of decontamination and decomissioning activities. The on-site waste generators are responsible for.

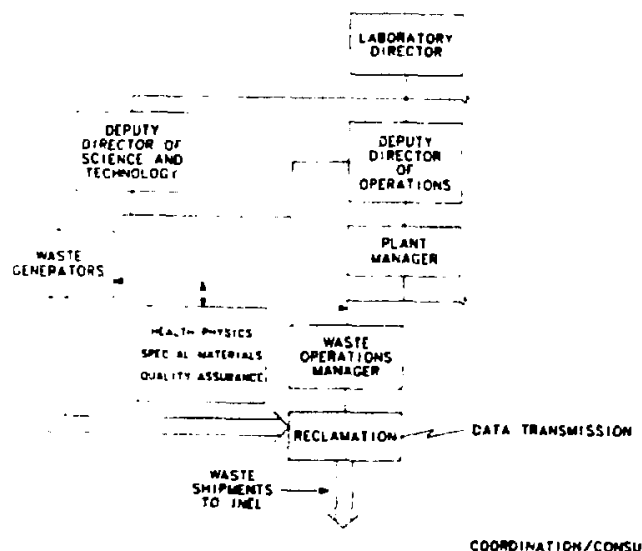

COOmolnation/CONSUL tation

Fig. 6. Waste managenent and related organizational structure at ANL. the contents of thetr own waste packages. Decontamination and decommissioning wastes and other TRU waste: are typically placed in wooden boxes or in 55-gal steel drums and then in $M-3\left(4^{\prime} X 5^{\prime} X\right.$ $6 \%$ steel bins. Primary waste containers are counted on a segmented scanner by the special Materials Division to determine fissile-materials content.

A well developed internal $Q A$ program is used to aid in internal certification. Essentially, visual inspections are used to check waste packages, and administrative procedures are used to control waste packaging. As with many other organizations, immobilization of waste is a concern at ANL. The Waste operations Manager will be responsible for modifying the QA program and developing the procedures necessary for certification. The Reclamation supervisor, who is respunsible for the handing and disposal of solid TRU waste and liquid waste, and for decontamination and decommissioning operations, will be the certifying authority at ANL.

Possibly all ANL waste can be certified in FY 1982 except for absorbed liquids. Absorbedliquid problems are mainly related to the more restrictive EG\&G Idaho acceptance criteria than to the WIPP Waste Acceptance Criteria. Decisions defining appropriate immobilization methods would be beneficial at an early date.

ANL is now handing all data collection and reporting requirements manually.

P. RHU

Solid wastes produced by the myriad facilities on the Hanford Reservation are stored on the 200 Area Plateau, which is managed by KHO. In addition to waste produced on site, TRU waste has been, and will continue to be, received from of $f-s 1$ te generators. Por example, classified TRU waste produced at RPP Is shipped to Hanford. Many organizations thip waste, including nondefense waste, to Hanford. Once on the reservation, the nondefense waste is not segregated from defense waste.

Figure 7 shows the structure of organizations related to waste managenent and certification. All the internal waste generators and lines of authorIty and comunication are not shown in Fig. 7 


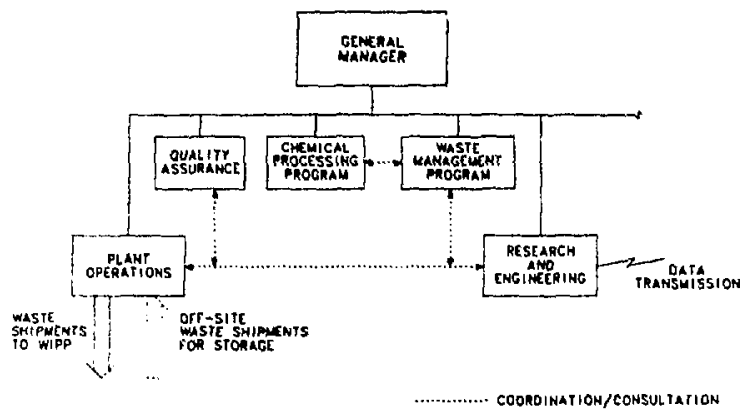

Fig. 7. Waste management and related organizational structure at RHO.

because the structure of RHO is too complex. The major organizations within RHO involved in the recelpt and storage of waste are Research and Engineering, the Waste Management Program office, and Plant operations. The $Q C, Q A$, and audit functions are under Quality Assurance, Data transmission to WIPP will be handled by Research and Engineering, which is the officlal records organization.

Cectification may be a difficult task at RHO because of the multitude of on-site and off-site waste generators. The off-site wastes are easier to certify because they must meet DOT and NRC regulations for transportation.

RFP is funding RHO to write certification procedures in FY 1982. An objective of RHO is to begin certifying TRU waste by the end of FY 1982. This will include $Q A$ and $Q C$ procedures. A QA manual entitled "Hanford Radioactive Solid Waste Packaging, Storage and Disposal Reguirements" (RHO-MA222), now under revision, will provide the basis for their $Q A$ regulrements for certification. Certification will be required of the waste generator; however, overall site certification, which will likely reside in Research and angineering, probably can only ensure that the generator followed procedures to met the WIPP waste Acceptance criteria. RHO will devote 2 maryr to certification in PY 1982.

Hany of RHO's concerns are similar to those of other site operators. Organic liquids can probably be detoxified and stabilized; however, toxic elements such as cadmium, beryllium, mercury, and lead must be addressed individually. In addition,
250 of the wastes contain nitrates and may require processing to meet the pyrophorlc materials criterion. Pinally, most boxes used to store TRU waste at Hanford exceed the size requirements of the WIFp Waste Acceptance Criteria.

Several studies will be initiated by RHO in Fy 1982 that will affect their future certification and disposal activities. One study will address the feasibility of a Waste Reprocessing and Packaging (WRAP) facility. Another study will investigate the use of a vibratory finisher to remove TRU contamination from large metal items, such as gloveboxes and hoods. This, if effective and economical, would convert the large metal items to low-level waste suitable for shallow land burial and $\mathrm{TRU}$-waste effluent stream with a much reduced volume. RHO personnel cite a need for sorting, size-reduction, incineration, immobilization, anc assay facilities as a minimum to achieve waste certification before shipment to WIPP. Decontamination and compaction processes will be recommended if economically justified.

Data processing at RHo is conducted on a new minicomputer that is linked to a DOE computer system operated by Boeing Computer Services and housed in the Federal Building in Richland, Washington. Together they generate data, some of which are later transmitted over SACNET to the SwIMS in Idaho Palls. RHO personnel do not use swIMS or the Integrated Data Base. Instead, they use their own data base system to keep track of waste and to generate various reports, including the quarterly reports. It is felt that the new computer system will allow RHO personnel to track indivioual waste containers through packaging and disposition.

\section{G. Los Alamos}

Figure 8 shows the waste management and related organizational structure at Los Alamos. Most of the TRU waste is generated by on-site operations, although small quantities are received at 25-yr intervals from the Lovelace Biomedical and Environmental Research Institute, Inc. On-site generators package most wastes in 55-gal drums and fiberglass-reinforced polyester (FRP) coated plywood boxes that are purchased Erom RFP. Visual inspection of containers for damage is the only 


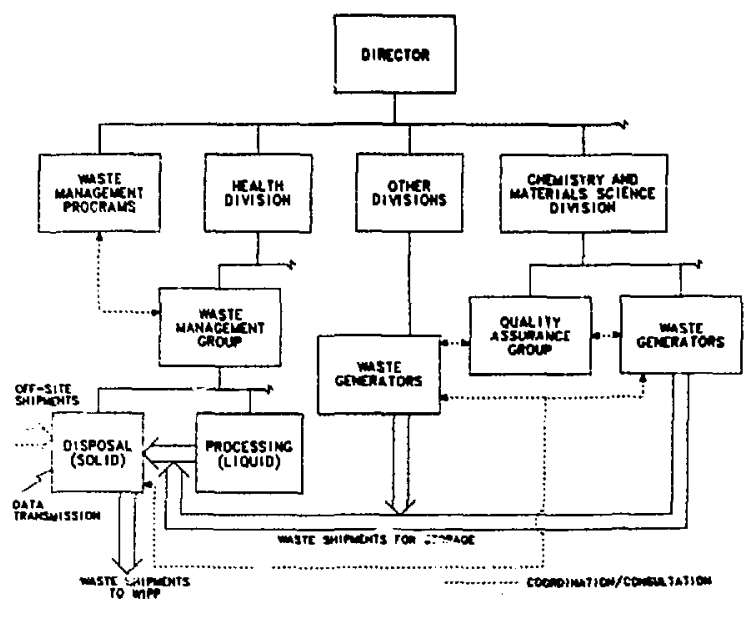

Fig. 8. Waste management and related organizational structure at Los Alamos.

new-container $Q C$ activity performed because of the effective $Q A$ program confucted by Rockwell International. Before waste packages are stored at the Los Alamos disposal site, they are visually inspected to ensure proper packaging by the waste generator. Shipping papers are reviewed by at least two Waste Management (Disposal) personnel before packages are stored at the retrievablestorage facility. LOS Mlamos waste Management personnel are famlliar with the generators' operations and use this knowledge to make consistency checks in their review of the package documentation.

Waste generators are responsible for both the contents and condition of their wate packeges. The Waste Management Group has developed waste acceptance protejures that detail what must be done before a waste package can be stored. The intent of the procedures is not only to promote sufe operations but also to define corrective actions. Each generator is required to have formal procedures, which are reviewed and approved annually by wate Management personnel. Los Alanos Waste Managewent has no formal QA procedures. They could, however, be developed in crnsultation with the Los alans Quality Assurasti: Group, with litele edditional effort.

The TRU wastes that have been at Los Alamos the longest time present more problems because some of them are too large or heavy, in the wrong form, or the contents of the packages are not well characterized. Special considerations must be addreased individually.

Approximately 125 oversize boxes are in storage at Los Alamos. This will not present a problem for shipment to WIPP because a size-reduction facility is under construction and should be operational by 1983. Most oversize boxes will be retrieved and processed in the size-reduction facility so that acceptable standard boxes can be used. Some newly generated waste may not meet the wipp waste Acceptance Criteriai contaminated soils and residues may need to be inmobilized to meet the immobilization criterion related to respirable fines. Clarification is necessary on what needs to be immobilized, and acceptable imrobilization methods need to be identified.

Los Alamos Waste Management personnel are initlating a study with the largest TRU-waste yenerator at Los Alamas to identify, in simple chemical terms, the composition of existing waste categories and, if necessary, to modify their categorization scheme. This will help to identify immobilization needs and to improve the effectiveness of the existing records system. A certifying authority for waste shipment to WIPP has not been identified, but it will probably rest with the waste shipper (Disposal). The general plan will call for the generator to conduct all procedures necessary for certification and for Waste Managewent personnel to provide an oversight function of the generators' activities.

Newly generated waste placed in storage as certified wate will be shipped to HIPP first, followed by existing stored wate after it is certified. Hewly generated waste stored as certified waste will be verified by visual inspection and other ceni-quantitative methods before shipment to WIPP.

The Waste Management Group handles the waste menegement records using alnicomputer. Data are avaflable in easily retrievable form for every container stored since 1971. Date necessary for swits reports alwo are handled with this system. The waste management Group (Disposal) can transait date packeges to WrP from the existing data files. 
Los Alamos should have little :rouble certifying some wastes by the end of FY 1902. However, a full certification program will require formal procedures that are approved at top management levels at Lo Alamos and by the responsible external authority yet to be designated. Moreover, it is estimated that one additional wate management employee will be necessary to help implement a certification program.

\section{H. SRP}

Figure 9 shows the waste management and related orgat.1zational structure of SRP and the Savannah River Laboratory, which are managed by the Atomic Energy Division of E. I. duPont de Nemours and Company. The responsibility for accepting on-site, certified TRU waste for storage and eventual shipent to WIPP will probably rest with waste Management Operations. SRP is planning certification studies in FY 1982; however, no certifying authorities have been identified yet within SRP. Currently, only the generators are participating in certification-like activities, auch the same as for other organization: we have contacted. If some certification does take place, it will probably consist only of an authority's certifying that the generators are following procedures that will allow their waste to deet the wipp waste Acceptance Criteria.

SRP has a well established QA group, whose capabilities are being investigated relative to the certification of TRU waste. SRP personnel

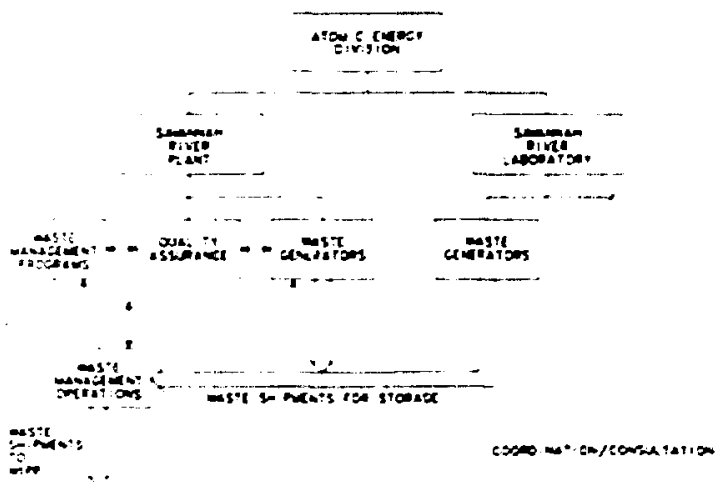

Pfg. 9. Wate mangeant and releted organizational structure at sis. suggest that the WIPP operatur should define the necessary level of $Q A$.

SRP and DOE Savannah River Operations office personnel belleve that one organization should be responsible for approving certification procedures. They think it should be either wipp personnel or the DOE organization responsible for the operation of WIPP. If wore than one organization is approving procedures, there will be a lack of consisLency. (DOE is wow preparing guidance on procedures to be used, and this will be published in the near future.)

SRP is planning to retrieve its stored waste; however, this is not recognized in wiPP documentation regarding transfer of retrleved waste to wipp. SRP personnel feel that retrieval of their waste should have a high priority Lecause theit s,te has a more humid environkent than that of INEL, which exacerbates the concern over radionuclide magration. SRP personnel further believe that the wip? Environmental Impact Statement (EIS) and the WIfP Haste Acceptance Criteria address only the waste management problems at INEL and RFP. Although KFP has a larger volude of waste, SRP's TRU waste has the largest curie content. Hence, SRP recomends that the WIPP EIS be amended or suppleaented to address the specific problexs associated with their $239 \mathrm{pu}$.

Other concerns at SRP are related to gas generation, combustibility, and packaging requitewents. Savansah River personnel would like to have approved containers specified. Single or double containsent on the Tru Package Iransporter (TRUPACT) is also a conrern, and they have contected the Transportation Technology Center of the Sandia National Laboratories. Albuquerque, to resolve this concern. Because of their waste types, SRP thinks the TRUPACTs should have double contaiment.

Currently, SRP has two parallel cfforts for long-tern Jyl-waste anugewent. One is to ixinerate the tho waste, conbine it with high-level wate, and then imobilize it for long-tera dispoation on site or for future shipent to a repository. The alternative is to ship the waste to MIPP in sccordance with the wIPP waste Acceptance Criteria. The direction finally choven will af Eect the level of eftort needed tor certification. 
BCI.'s major source of contzct-handled TRU waste has been the1r Plutoniun Laboratory. This facility has been shut down since the end of 1977 and decontanination and decomissioning operations are nearing completion. AIL TRU wastes generated from research and developont prograse and from the decontaniration and decomissoning operatione have beres shipped to INEL for retrievable storage. It is estiated that during the final decontamination and decomissioning phase of this facility, an additional 15 drums and possibly 4 bins of TRU waste might be produced. hfter completion of these activities, it is estimated that a comblned generation rate of $575 \mathrm{ft}^{3} / \mathrm{ir}^{\mathrm{r}}$ of contact-hanniled rid waste will be produced from the BCL Radiochemistry Laboratory and fram a small, ehree-glovebox laboratory faclity that is planned.

The atove information was collected by a telephone conversation and a letter from BCL. No site visit was made.

VI. CONCLUSICAS AND RECOMENDATIOHS

The WIPP waste Acceptonce Criteria we developed primarily to ensure safe waste transport to and operations at WiPP. Clarification of the WIPP waste Acceptance Criteria has received considerable dtention, and the findings of a DOE contractor: Certification Pequirement: Horking Grop was publistea as a WIPP-DoE series document. ? Our interactions with the mafority of Tral-uaste generators and shippers lead us to conclude that there is d recoanition of the reed to reorient local waste managenent activities to met the requirements of WIPP. Specific areas that need attention are surarized in the following sections.

\section{A. Certification Authority}

The eajor problem ve Identffied is the absence of an organixation remponglble for approving certification, QA, and traneportation procedures. Currently, no vaste generator. or ahippers have been formaly charged by DOE either to certify their wastes or to develop waste certiflcation and QA procedure that would enture conformance with the WIPP Wate Acceptance Criteria. A formal request for certification should be made imediately by DOE Headquarters, and an authority responsible for epproving site-specific certification prigrams should be identifled. Personnel at most ates suggest that a central organization should be responsible to avold potsible inconaistencies. Farthermore, an arbitrator of disputes between the wate shippers and WIPP needs to be identified.

Most of the contractors have well developed QA prograns. The DOE-WIPP Project office way be required to approve the levei of $Q A$ procedures or wy merve only in an advisory or consultation rale. It would be beneficial to have a neeting of all the contractor and WIPP personnel to discuss different aspects of the level of QA that will be necessary for the certification program. This neeting hould be scheduled after the responsible DOE organization(s) is Identified. The Qh procedures should be simple to minimize the operators. efforts to certify their wate. The QA progran that the shippers subait to $D O E$ should state tow they will aet the soquirements, their related organizational structures and levels of authority, and their data collection procedures. A separace QA authority could guide the waste management peronnel (shipper) in developing procedures for a $Q C$ progras. Ides $2 y$, wate management personnel would be in coniact with generators, when necessary, to provide guldance and assistance.

\section{a. Waste Certification Training}

We recownend that RFP waste managewent perconnel, In congultation with IwSO, provide seminars on she procedures that are presently being dereloped at RP to make their neuly generated TRU waste contorm to the WIPP certification requirements. Invited attendees should include the people who are devejoplng and implementing $Q A / Q C$ and certification procedures. If necessary, a separate 1-day sealnar could be conducted, through mso, for managment peraonnel. Through this exchange of ideas the shippere probably would be able to certify nowly generated tho wate sooner and with less expense than if they each try to develop procedurea Independently. 


\section{Waste Packaging}

Two of the major cancerne of TRu-wate generators and shipper. have bean (1) the waste forms acceptable at wrpp and (2) the container for ahipping to WIPP, TwSo should provide input to waste generators and shippers concerning the experiences of DOE-supported wate-form development activitles. Some spectfic suggestions to all generators and shippers at an early date are desirable. Much of the concern regarding containers is justified because the contractors have waste-handling equipant that. would be experaive to roplace if they were required to use concainers not matched to their equipment. However, exemption alght be considered for snall waste generators having containers smaller than those specifled by the compliance requirements. Otherwise, the contents of the containers could, perhaps, be processed at INEL. Small waste operations using iarger than approved containers should be exempted from the EGcG Itaho acceptance criteria sc that the wate can be processed at INEL. The financial implications of these waste packaging concerns can be enormoun, and the ability of the waste generators to produce certified waste in FY 1982 depends on funding aval1ability.

\section{Haste Documentation}

Standardization of forms and reporting procedures should be addressed imediately. Different contractors have different data collection, reporting, and processing systens, often primarily depigned for accountability or nuclear materials control. It would be beneilclal to develop a standdrdized reporting procedure for futire waste generation. One way to accomadate the old recordskeeping methods would be to change the old records on an as-can basis after the new procedures are implemented.

\section{E. Standard Labe is}

Standardization of container labeling, color coding, and code location should be addressed imediately.

\section{F. Data Processing}

Every contractor has his own approach to computer syatems for collecting, collating, processing, and transmitting data. In addition to the Mound computerized records system discussed in Sec. $V$, there are several other systems or partia! systems. ORNL has the Integrated Data Base, RFp has the mis, RHO has a waste management system, and EGcG Idaho has a separate WMIs and the SwIMS. EGsG Idaho plans to dedicate a computer to the i: waste operations using NOMAD ${ }^{2 l}$ for data base handing. In addition, they plan to use this $\mathrm{com}^{-}$ puter system to generate the data for SWIMS. RFP and RHO are using SACNET to transmit data to INEL.

Twso has provided funding in FY 1981 and hats buageted FY 1982 funding for the Mound Facility to modify its waste management computer system to include additional features necessary for a totally nutomated records system to support cortification activities. Future plans call for the adaptation of this systen to other sites, where appropriate. Modiflcation of the computer system at Mound will not be completed in PY 1982, and installation at another stte probably would require $\geq 2$ yrs. Mound personnel plan to form a committee in early Fy 1982 to discuss their system with a:l site operators.

Although the Mound system may not be easily adapted to some sites, Mound's plan to meet with other site personnel in early Fy 1982 is desirable. This comittee should include a representative from Westinghouse-WIPP and from Bechtel. Before additional funding is appropriated for the development of any or several computer systems, the problem should be thoroughly studied, possibly within 6 months. It may be that no single system will be feasible, with each site having its own hardware and software needs. However, the output from these site-specific systems should be in a single, standard form and should be easily transmitted to HIPP.

\section{G. Additional Concerns}

Exaples of additional concerns include gas generation and coabustible waste. For gas gereration, if a vent is required for waste containers, 
the vent could be plugged to meet DOT requiremente for shipment, and then unplugged after receipt at WIPP. For combutible wate, INEL plan to thip then to WIPP unless Incineration or some other volume-reduction method is more cost effective. The concern with centralized vo decentralized (onsite) incineration or processing faclitties is an economic concern, and early policy decisions are necessary * Continuing efforts to assers objectively the concerns of all the program participants under the auspices of Twso should facilitate the development of practicable interfaces between TRUwaste shippers and WIPP.

\section{ACKNONLEDGMENTS}

The authors are indebted to the individuals listed in App. B who contributed to this report.

The authors gratefully acknowledge the helpful suggestions and criticisms of R. J. Merlini and $D$. w. Rutherford of TWSO, RFP; and of J. P. Shipley, E. A. Hakkila, and $A$. L. Baker of the Salieguards Systems Group, Los Alamos National Laboratory. S. I. Klein, K. C. Eccleston, and P. H. Mayne typed the report, and $K . J$. Woodward and $M$. I. Bonner prepared the figures.

\section{REFERENCES}

1. "Report of the steering Cormittee on TRU Waste Acceptance Criterla for the Waste Isolation Pilot Plant," H. H. Irby, Ed., US DOE report NIPP $\rightarrow$ DOE-069 (May 1980).

2. "TRU Wagte Certification Compliance Requirements for Newly-Generated Contact-handled wastes for Shipment to WIPP," Rockwell International, Transuranic Waste Systems office draft report (July 1981).

3. "TRU Waste Acceptance Criterla for the Watte Isolation Pllot Plant," US DOE report NIPPDOE-069, Rev. 1 (Septenber 1981).

4. "Final Environmental Impact Statement, Haste Isolation Pilot plant," US DOE report DOE/EIS0026 (October 1990), Vol. 1.

5. Maste Isolation Pilot Plant Safety Analyais Report," US DOE report (January 1981), Vol. 5.

6. Some Preliminary Interpretations of WIPP TRU Waste Acceptance Criteriap" Rockwell International, Transuranic wate Systens office circulated, unpublished document (March 1981).
7. WRU Waste Certification Compliance Requirement: for Newly-Generated Contact-handled Waste for Shipment to the WIPP," US DOE report WIPP-DOE-114 (October 19B1).

8. "Design Criteria: Revied Misaion Concept-II, Wate Isolation PIlot Plant (WIPP)," US DOE report WIPP-DOE-71 (Hay 1980 ).

9. "Computer System and Data Processing Requirements for the waste Isolation Pllot plant (WIPP)," in "WIPP Conceptual Design Report," Sandia Laboratories report SAND-77-0274 (June 1977). Addendun $M$.

10. B. C. Anderson, "Criteria for Fackaging waste for Receipt at the Idaho Naticnal Engineering Laboratory Radioactive Waste Management Complex, offsite Generated waste," US DOE Idaho operations office report IDO-10074, Rev. I (April 1980, changed May 1981).

11. H. M. Batchelder and R. W. Passmore, "Solid Waste Information Management System (SWIMS), SWIMS Users Manual," EGEG Idaho, Inc. report (September 1977 ).

12. C. A. Johnson and P. A. Garland, "Radioactive waste Management Integrated Data Base: A Bibliography," Oak Ridge National Laboratory report ORNL/TH-7385/V1 (September 1980).

13. "Spent Fuel and Radioactive Waste Inventories and Projections as of December 31, 1980," Us DOE report DOE/NE-0017 (September 1981).

14. N. R. Atencio, M. A. Bloomstran, and L. E. Trujillo, "Waste Management Information System," Rockwell International, Energy Systems Group report CHOP-9305.79-02 (November 1979).

15. SACNET System Sumnary," US AEC Albuquerque Operations office report (February 1974 ).

16. "Users' Handbook: Waste Accountability Shipping and Packaging (WASP)," Mound Facility Technical Hanual MD-10173, Issue 1 (July 1981 ).

17. J. A. Jackson, M. Baston, and E, A. DeVer, "A Computerized Waste Accountability and PackagIng System," Nucl. Mater. Manage. $x, 48-51$ (1981).

18. "Users Manual for Automated 741 Nuclear Material Tranffer Reporting System," US DOE $\Lambda 1 b u-$ querque Operations office report (March 1980).

19. "Control and Accountability of Nuclear theterials, Basic Principles, “ US DOE Order 5630.2, Chap. II, sec. 5a (August 1980).

20. "Procedures for Use of Nuclear Materials Reporting and Data Procesaing Porms," US DOE Order 5630.8 (July 1980$)$.

21. D. R. Ries, Feature Analysia of Relational Concepts, Languages and Systens for MOMD and Nownd2," University of California, Livermore report ucrD-18843 (October 1980). 


\section{Criteria}

1. Gas generation
Contact-Handled (CH) Waste

- Shall not exceed $10 \mathrm{~mol} / \mathrm{m}^{3}$ of storage-room volume/yr or

- The organic content may not exceed:

(a) $220 \mathrm{~kg} / \mathrm{m}^{3}\left(14 \mathrm{lb} / \mathrm{ft}^{3}\right)$ in $210-\mathrm{L}$ drums

(b) $100 \mathrm{~kg} / \mathrm{m}^{3}\left(6 \mathrm{lb} / \mathrm{ft}^{3}\right)$ in other containers

2. Combustibility

3. Immobilization

4. Prohibited materials at WIPP materials (nonradioactive)

6. Toxic and corrosive materials

7. Containers and overpacks

8. Waste package

\footnotetext{
9. Haste package weight

10. Waste package size
}

Noncombustible containers must
- Powders, ashes, and similar particulate materials shall be immobilized if the waste matrix contains $>1$ wt of particles $<10-\mu$ diam or >15 wt of particles $<200-\mu$ diam

- Sludges

- Free liquids

- Explosives

- Compressed gases

- All forms must be rendered safe

- Pyrophorie radionuclideg should be $\leq 1$ wt of wastse

- Toxics must be identified and approved; corrosives must be rendered noncorrosive

- Shall be noncombustible and meet the requirements of 49CFRI73.398(b) for Type A packaging

- Danaged containers shall be overpacked

- Deaign life of the containers shall be at least 15 yrs after emplacement, including labeling and color coding

- All containers need prior approval by WIPP

- Containers must have cleats, offsets, chines, or skids for handing by fork trucks, cranes, etc.

- Max. $11300 \mathrm{~kg}$ (25 000 1bs)

- May not exceed $3.7 \times 2.4 \times 2.5 \mathrm{~m}$ in overall LxhxH dimensions (12x8x8.5 ft) be used for combustible waste
Remote-handled (RH) waste

Not specified

Same as $\mathrm{CH}$

Same as $\mathrm{CH}$

Same as CH

Same as $\mathrm{CH}$

Same as $\mathrm{CH}$

Same as $\mathrm{CH}$.

Same as $\mathrm{CH}$

Same as $\mathrm{CH}$

Must have axial lifting pintle for remote handling. other auxiliary devices are not permissible

Max 3200 k. (7000 1bs)

shall be cylinders of $0.6 \mathrm{~m}(2 \mathrm{ft})$ in diam with a maxinum length of 3.1 . (10 $\mathrm{ft}$ ) including the pintle 
11. Surface dose

12. Surface contamination

13. Thermal power

14. Nuclear criticaltey

15. Certification

16. Waste-documentation system

17. Labeling

18. Color cocing

19. Data-package transmittal
- Max: $200 \mathrm{mrea} / \mathrm{hr}(2 \mathrm{mSv} / \mathrm{hr})$ at any point. Color codirg required when $>10 \mathrm{mrem} / \mathrm{h}$, $\leq 200$ mren $h$

Max: $100 \mathrm{rea} / \mathrm{hr}$

(1 Sv/hr) (internal shtelding may be used)

- $550 \mathrm{Di} / 100 \mathrm{~cm}^{2}\left(1.9 \mathrm{Eg} / 100 \mathrm{~cm}^{2}\right)$

Sane as CH for $a-$

$-\leq 450 \mathrm{DC} 1 / 100 \mathrm{~cm}^{2}\left(16.7 \mathrm{~Bq} / 100 \mathrm{~cm}^{2}\right)$ for $B-, y-$

$->3.5 \mathrm{w} / \mathrm{m}^{3}\left(0.1 \mathrm{w} / \mathrm{ft}^{3}\right)$ must be recorded in data package

- Fissile-isotope content is 1 imited to: $<200 \mathrm{~g} / 55 \mathrm{gal}\left(0.21 \mathrm{~m}^{3}\right)$ or larger drums $<100 \mathrm{~g} / 30 \mathrm{gal}\left(0.11 \mathrm{~m}^{3}\right)$ drum $\leq 500 \mathrm{~g} /$ DOT $6 \mathrm{H}$ container $<350 \mathrm{~g} / 4 \times 4 \times 7 \mathrm{ft}(1.2 \times 1.2 \times 2.1 \mathrm{~m})$ FRP DOT 7A box $<5 \mathrm{~g}$ in any $\mathrm{ft}^{3}\left(0.028 \mathrm{~m}^{3}\right)$ in other noxes

- Generation and shipping sites must provide a data package certifying that each waste package meets the wIPP-WAC

- Shipping sites must maiutain auditable documentation

- Documentation system must include :

(a) Description of: methods of certification

(b) Quality assurance and safety requirements

- Mll federal labeling requirements must be met

- In addition, each waste package must have a label that will uniquely identify it. Information will include:

(a) Standardized package identification number

(b) Weight in kilograms

- WIPP operator will prescribe the code

- The code must be designed to identify:

(a) Surface dose rate

(b) Combustible contents (1E >25 vols)

(c) Toxic material content

- Data package shall be transmitted to WIPP before shipping waste package
Thermal power shall not exceed $300 \mathrm{H}$ per package

$<5 \mathrm{~g} / \mathrm{ft}^{3}\left(0.028 \mathrm{~m}^{3}\right)$ All others will be reviewed on an individual basis

same as CH

Same as $\mathrm{CH}$

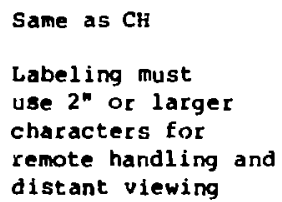

Not specified

Sane ag CH 
20. Data package (contents of ...)

- Package ID number

Same as $\mathrm{CH}$

- Certification statement

- Waste-generation site

- Date of packaging

- Radiation levels

- Weight

- Contalner type

- Phyajcal description of waste

- Asuay information

- Nonradfoactive hazardous materfals

- Weight of organics

- Thermal power (1f $>0.1 \mathrm{w} / \mathrm{ft}^{3}$ )

- Date of shipment

- Carrier identification

- Other oignificant information (if any)

Thie append $t x$ was adapted from us DOE report WIPP-DOE-069, Rev. 1. 
PERSONNEL AND ORGANIZATIONS CONTACTED

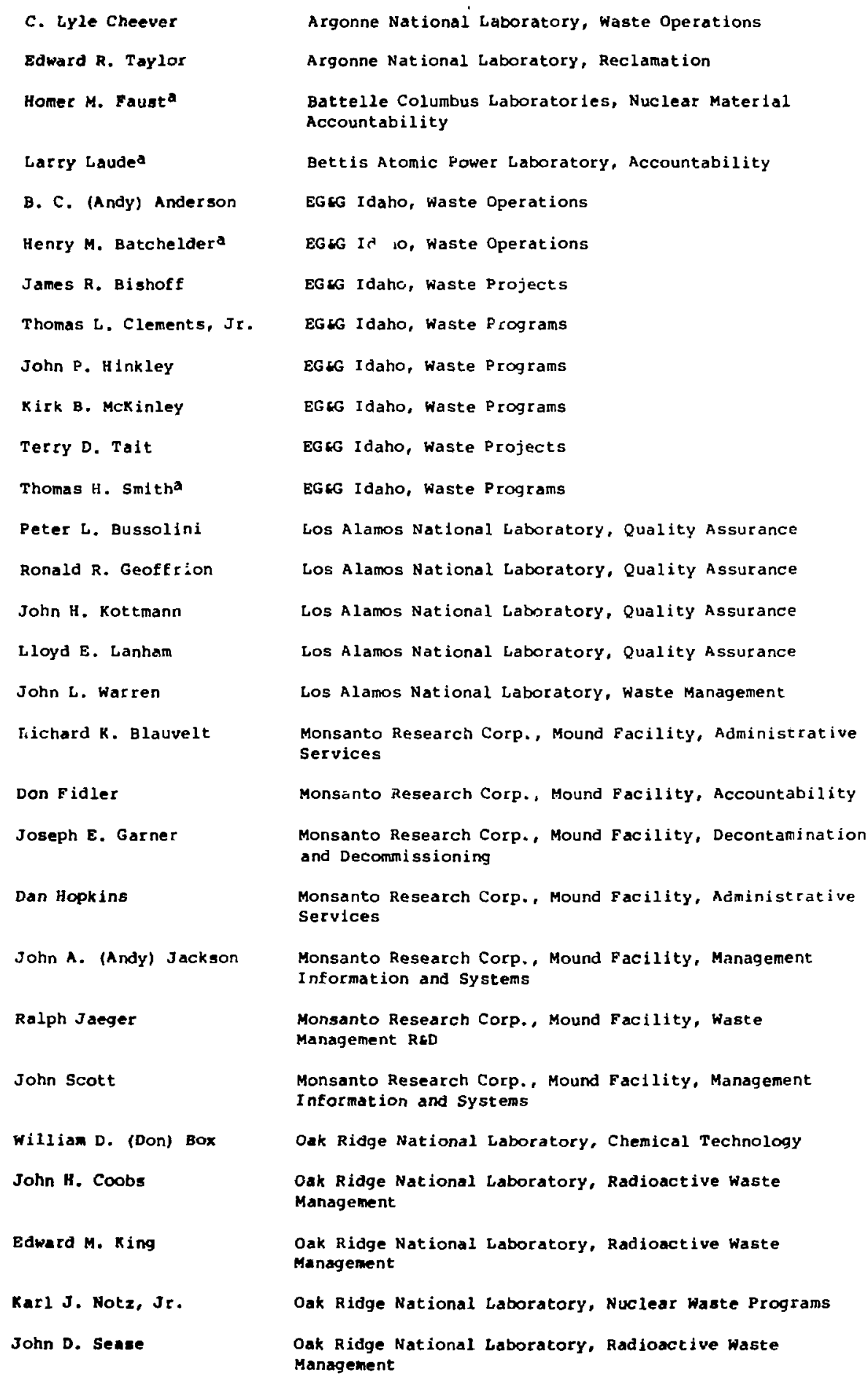


Jame: F. Albaugh

Janes Ander son

Roy Benton

Richard wojtasek

Marcus A. Aguilar

William F. Bates

John A, Hayden

L. E. (Eloy) Trujillo

Wayne $\bar{E}$. Wendell

Charles E. Wickland

Richard J. Merlini

David w. Rutherford

George $W$. Becker

Arthur L. Coogler

Richard G. Baxter

Jan Epting

B. D. (Don) Helton

Gary H. Johnson

Ed O'Rourke

Cary B. Stevens

William F. Lawless

H Ichael H. McPadden

Joseph M. McGough

Dennis R. Arter

Craig L. Fredrickson

J ack E, Johnson

vincent F. Likar

Mark M. Merrion

Kenneth R. Mikus

John w. Sadler
Rockwell Hanford Operations, Waste Storage and Diaposal Program

Rockwell Hanford Operations, Process Eng ineering

Rockwell Hanford Operatione, Quality Assurance

Rockwell Hanford Operations, Systems Engineering

Rockwell International, Rocky Plats Plant, Waste Operations

Rockwell International, Rocky Flats Plant, waste Operations

Rockwell International, Rocky Flats Plant, Waste Operations

Rockwell International, Rocky Flats Plant, Process Control Operations

Rockwell International, Rocky Flats Plant, Quality Engineering Systems and Plans

Rockwell International, Rocky flats Plant, waste Operations

Rockwell International, Transuranic Waste Systems Office Rockwell International, Transuranic waste Systems office Savannah River Laboratory

Savannah RIver Laboratory

Savannah River Piant, Waste Management Prograns Savannoh River Plant, Waste Management Programs Savannah River Plant, Waste Managenent Programs Savannah River Plant, Waste Managenent Operations Savannah River Plant, Waste Managenent Programs Savannah River Plant, waste Management Programs US DOE, Savannah River

US DOE, waste Management and Transportation Developmient Division

US DOE, WIPP Project office

Wustinghouse Hanford, Nuclear Quality Assurance Program offlce

West inghouse-wIPP

West inghouse-WIPP, wIPP Eng ineering

Westinghouse-WIPP, Radfoactive Materials Operations

Hestinghouse-WIPP, Data Processing

Westinghouse-WIPP, Data Processing

Wentinghouse-WIPP, Mechentcal and Electrical Systems

Telephone conversation. 